\title{
Peanut Seed Vigor Evaluation Using a Thermal Gradient
}

\author{
Timothy L. Grey, ${ }^{1}$ John P. Beasley Jr., ${ }^{1}$ Theodore M. Webster, ${ }^{2}$ and Charles Y. Chen ${ }^{3}$ \\ ${ }^{1}$ Crop and Soil Science Department, College of Agriculture and Environmental Sciences, University of Georgia, Tifton Campus, \\ P.O. Box 748, 115 Coastal Way, Tifton, GA 31794, USA \\ ${ }^{2}$ Crop Protection and Management Research Unit, USDA-ARS, 2747 Davis Road, P.O. Box 748, Tifton, GA 31793-0748, USA \\ ${ }^{3}$ National Peanut Research Laboratory, USDA-ARS, 1011 Forrester Drive, SE, P.O. Box 509, USDA-ARS, Dawson, \\ GA 39842-0509, USA
}

Correspondence should be addressed to Timothy L. Grey, tgrey@uga.edu

Received 23 March 2011; Accepted 10 June 2011

Academic Editor: Allen V. Barker

Copyright ( 2011 Timothy L. Grey et al. This is an open access article distributed under the Creative Commons Attribution License, which permits unrestricted use, distribution, and reproduction in any medium, provided the original work is properly cited.

\begin{abstract}
Experiments conducted from 2007 to 2009 evaluated germination of 11 peanut runner-type cultivars. Germination was evaluated in Petridishes incubated over a thermal gradient ranging from 14 to $30^{\circ} \mathrm{C}$ at $1.0 \mathrm{C}$ increments. Beginning $24 \mathrm{hr}$ after seeding, peanut was counted as germinated when radicles were greater than $5 \mathrm{~mm}$ long, with removal each day. Germination was counted daily for seven days after seeding. Growing-degree day (GDD) accumulation for each temperature increment was calculated based on daily mean temperature for that Petri dish. Two indices were obtained from a logistic growth curve used to elucidate seed germination by cultivar: (1) maximum indices of germination and (2) GDD value at $80 \%$ germination $\left(\mathrm{Germ}_{80}\right)$, an indication of seed vigor the lower the Germ $_{80}$ value, the greater the seed lot vigor. Based on the two indices, seed lots "AT 3081R", "AP-3", "GA-06G", and "Carver" had the strongest seed vigor (Germ 8026 to 47 GDD) and a high maximum incidence of germination rate ( 80 to $94 \%$ ). Seed lots of "C99-R", "Georgia-01R", "Georgia-02C", and "Georgia-03L” had inconsistent seed performance, failing to achieve 80\% germination in at least two of three years.
\end{abstract}

\section{Introduction}

United States peanut production in 2010 (510,308 ha) centered mainly in the southern states of Georgia $(226,623 \mathrm{ha}$, $44 \%)$, Alabama (75,676 ha, 15\%), Florida (54,632 ha, 11\%), North Carolina $(35,612$ ha, $7 \%)$, South Carolina $(26,605$ ha, $5 \%)$, and Mississippi (7,284 ha, 1\%), with another concentration in the south central states of Texas $(64,749$ ha, $13 \%)$ and Oklahoma (8,094 ha, 2\%) [1]. The value of peanut to these regions exceeded one billion US dollars in crop sales each year [1]. Producers plant many different cultivars across this region including runner and Virginia market types. Regardless of where peanuts are grown, poor seedling emergence can be an issue [2].

Prior to the 1990s, producers in the southeast planted peanut beginning in early April [3]. However, the incidence of tomato spotted wilt Tospovirus (TSWV) increased rapidly across the peanut belt in the 1990s, especially on susceptible cultivars [4]. Research indicated that later planting date could decrease TSWV incidence, and therefore a shift toward mid- to late-May planting of peanut occurred [5]. Peanut breeding efforts were focused on developing TSWV-resistant cultivars [4]. Initial studies from 1998 to 2000 indicated that cultivars tolerant or resistant to TSWV could be successfully grown with minimal yield losses if growers planted in May [5, 6]. "Georgia Green" [7] became the standard for peanut production in the southeast US in part because of resistance to TSWV [6], even if it has only moderate field resistance when planted in April [4]. Breeders have continued to develop new peanut cultivars with TWSV resistance [8-10], even relying on wild-type germplasm to incorporate TSWVresistance [11]. One goal is to generate cultivars that could be planted in April, with minimal losses to TSWV. This would increase producer flexibility for planting and harvest by expanding the growing season (i.e., currently from May to November that could change to April to be from November).

Seed quality has become a greater problem with the increase in TSWV-resistant peanut cultivars in the southeast US [12]. Specifically, Georgia 01-R and York were peanut cultivars that had germination and stand establishment issues 
for growers in Georgia. Field testing and evaluation of advanced breeding lines of the newly released cultivars did not indicate germination problems, but when taken to producer fields, some cultivars did not perform as expected. This has caused TSWV resistant cultivars not to be accepted by growers. Even though standard seed germination testing was used to evaluate the seed lots of these peanut cultivars, this has not always guaranteed adequate performance in a field environment. Seed can be a substantial cost of growing peanuts and replanting is expensive. Therefore, planting cultivars with high incidences of germination are essential for maximum net return on input costs. Additionally, seed dormancy existed as a primitive trait in A. hypogaea, but with advances in breeding programs, this has become less of a concern [13]. Since peanut produces seed in soil, plants must be inverted and allowed to dry prior to harvest, also known as "curing." However, plant curing methods have been known to cause a cultivar to express variable levels of seed dormancy related to biochemical and physical (seed coat) factors [14]. While standard seed germination testing is used to predict stand establishment, it is not guaranteed due to phenotypic (soil moisture and temperature) and genotypic factors [15]. Therefore, vigor testing can be utilized to evaluate seed for successful field establishment under different environmental conditions [16]. Peanut vigor testing has been conducted using tetrazolium, electrical conductivity, and cold test [17] for the cultivar "Georgia Green" [7], but peanut cultivars are continuously introduced replacing older cultivars with newer germplasm that need to be tested. While strong primary seedling development in standard germination testing is regarded as an indicator of strong vigor [18], this does not always translate into adequate field performance.

One method of testing seed quality, performance, and vigor is the use of a thermal gradient device [19-21]. This method has been used for weed and other crop seed evaluations to determine speed of germination and vigor. A thermal gradient allows the investigator to examine a single seed lot or multiple seed lots at differing temperatures simultaneously without the use of growth media such as soil or growth chambers. However, due to equipment size limitations to generate a wide temperature gradient and data acquisition required for thermal gradient experiments, this method has not been used for routine seed evaluation.

The objectives of this research were to determine if a thermal gradient method could be used to evaluate multiple peanut seed lot samples simultaneously to predict seed viability and vigor. Additionally, these results were compared to standard peanut seed germination tests to predict seed viability and vigor, and to evaluate whether this method could assist with future peanut cultivar development.

\section{Materials and Methods}

2.1. Seed Selection. Experiments were conducted from 2007 to 2009 on peanut seed lots certified by the Georgia Crop Improvement Association. These were single seed lots randomly selected from Georgia field grown supplies from the previous season. All samples had been stored from
September of the harvest year until the following March at a constant temperature $\left(5^{\circ} \mathrm{C}\right)$ and relative humidity $(10 \%)$. Cultivars for which seed lots were evaluated in all three years of the study included "AP-3" [22], "Georgia Green" [7], "AT 3085RO," "Georgia-02C" [23], and "C-99R" [24] (Table 1). Seed lots of four cultivars were evaluated in 2006 and 2007 including "Georgia-03L" [25], "Carver" [26], "AT 3081R" [27], and "Georgia-01R" [28], while two cultivars were evaluated in only 2007 and 2008, "Georgia-06G" [29] and "York." Seed were all treated with a fungicide prior to sampling by the processor.

All seed were tested according to official seed testing criteria for peanut [18] by an independent laboratory and presented in Table 1 , with testing for 10 days at $25^{\circ} \mathrm{C}, 50$ seeds by four replications (200 total seed). Seed response to temperature and time for all seed to germinate were then evaluated on a thermal gradient table [19].

2.2. Thermal Gradient Testing. The table was constructed from a solid aluminum block measuring $2.4 \mathrm{~m}$ long by $0.9 \mathrm{~m}$ wide by $7.6 \mathrm{~cm}$ thick with a mass of $470 \mathrm{~kg}$. On either end of the aluminum block, a $1.0 \mathrm{~cm}$ hole was drilled across the side section to allow fluid to be pumped into the table. On either end of the table, 14 or $35^{\circ} \mathrm{C}$ ethylene glycol plus water ( $1: 10$ mixture) were pumped at $3.8 \mathrm{~L}$ per min to generate the thermogradient. Along the length of the thermogradient, approximately $1.0^{\circ} \mathrm{C}$ increments occurred every $10 \mathrm{~cm}$, with a constant temperature across the width. This allowed for 24 increments across the length to obtain different temperatures, with nine increments across the width at each temperature, similar to Cardina and Hook [19], resulting in 216 total cells. One hundred thermocouples (made from duplex insulated PR-T-24 wire, Omega Engineering, Inc Stamford, CT) were randomly mounted to the underside of the table from the hot to cold ends. Each thermocouple was placed into tubing (Omega Engineering, Inc Stamford, CT) that was $8 \mathrm{~cm}$ long, $4.8 \mathrm{~mm}$ inside diameter, and $7.9 \mathrm{~mm}$ outside diameter. This was then inserted vertically into a hole on the underside of the table. Holes measured $8 \mathrm{~mm}$ wide by $7 \mathrm{~cm}$ deep to allow the thermocouple to be within $0.5 \mathrm{~cm}$ of the upper table surface, at $10 \mathrm{~cm}$ intervals along the length of the table. Initial data indicated a continuous temperature gradient ranging from 14 to $35^{\circ} \mathrm{C}$ along the length of the table. Temperature was monitored continuously for each thermocouple and recorded at $30 \mathrm{~min}$ intervals with a Graphtec GL450 midi data logger (MicroDAQ, com Ltd., Contoocook, NH), all temperature data for each thermocouple was downloaded daily in a spreadsheet format to a computer.

2.3. Seed Testing. Peanut seed for the appropriate seed lot of each cultivar were randomly distributed on germination paper (SDB $86 \mathrm{~mm}$, Anchor Paper Co., St. Paul, Minn), which was placed in a 100 by $15 \mathrm{~mm}$ sterile plastic Petri dish (Fisher Scientific Education, Hanover Park, Ill). Ten seed were placed in each Petri dish followed by the addition of $10 \mathrm{~mL}$ of distilled water. For each seed lot cultivar, a single Petri dish was placed at each $1.0^{\circ} \mathrm{C}$ increment every 


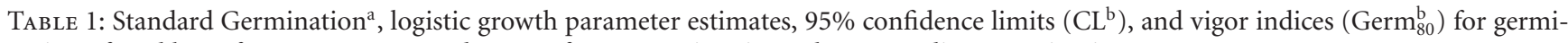
nation of seed lots of 11 runner type, and peanut from Georgia using a thermogradient germination assay.

\begin{tabular}{|c|c|c|c|c|c|c|c|c|c|c|c|c|}
\hline \multirow[b]{2}{*}{ Cultivar } & \multirow[b]{2}{*}{ Year $^{\mathrm{a}}$} & \multirow[b]{2}{*}{ Germination $^{\mathrm{a}}$} & \multicolumn{3}{|c|}{ Parameter $a^{\mathrm{c}}$} & \multicolumn{3}{|c|}{ Parameter $b 1^{\mathrm{c}}$} & \multicolumn{3}{|c|}{ Parameter $b 2^{c}$} & \multirow[b]{2}{*}{ Germ $_{80}$} \\
\hline & & & Maximum rate & $95 \%$ & & Estimate & $95 \%$ & & Estimate & $95 \%$ & & \\
\hline \multirow{3}{*}{ AP-3 } & 2006 & 93 & 92.4 & \pm 1.6 & $a^{d}$ & 5.8 & \pm 1.4 & $a^{d}$ & 0.18 & \pm 0.02 & $a^{d}$ & 26 \\
\hline & 2007 & 92 & 91.6 & \pm 1.4 & $\mathrm{a}$ & 3.3 & \pm 0.9 & $\mathrm{~b}$ & 0.21 & \pm 0.02 & $\mathrm{a}$ & 25 \\
\hline & 2008 & 87 & 82.5 & \pm 1.6 & $\mathrm{~b}$ & 1.7 & \pm 0.7 & c & 0.18 & \pm 0.02 & $\mathrm{a}$ & 40 \\
\hline \multirow{2}{*}{ AT $3081 R$} & 2006 & 96 & 89.8 & \pm 2.1 & $\mathrm{a}$ & 8.6 & \pm 2.2 & $\mathrm{a}$ & 0.16 & \pm 0.02 & $\mathrm{a}$ & 27 \\
\hline & 2007 & 91 & 84.6 & \pm 1.7 & $\mathrm{~b}$ & 4.8 & \pm 1.2 & $\mathrm{~b}$ & 0.17 & \pm 0.02 & $\mathrm{a}$ & 32 \\
\hline \multirow{3}{*}{ AT 3085R0 } & 2006 & 98 & 91.9 & \pm 1.8 & $\mathrm{a}$ & 6.5 & \pm 1.5 & $\mathrm{a}$ & 0.17 & \pm 0.02 & $\mathrm{a}$ & 27 \\
\hline & 2007 & 91 & 84.6 & \pm 1.7 & $\mathrm{~b}$ & 4.8 & \pm 1.2 & a & 0.17 & \pm 0.02 & a & 34 \\
\hline & 2008 & 78 & 74.6 & \pm 1.6 & c & 0.9 & \pm 0.5 & $\mathrm{~b}$ & 0.19 & \pm 0.02 & $\mathrm{a}$ & NA \\
\hline \multirow{3}{*}{ C-99R } & 2006 & 83 & 72.4 & \pm 2.3 & c & 5.3 & \pm 1.7 & $\mathrm{a}$ & 0.14 & \pm 0.02 & $\mathrm{~b}$ & NA \\
\hline & 2007 & 91 & 61.7 & \pm 1.9 & $\mathrm{~b}$ & 3.0 & \pm 1.2 & a & 0.17 & \pm 0.03 & $a b$ & NA \\
\hline & 2008 & 93 & 80.7 & \pm 1.4 & $\mathrm{a}$ & 0.8 & \pm 0.4 & $\mathrm{~b}$ & 0.22 & \pm 0.02 & $\mathrm{a}$ & 43 \\
\hline \multirow{2}{*}{ Carver } & 2006 & 79 & 83.8 & \pm 2.2 & $\mathrm{a}$ & 6.3 & \pm 1.9 & a & 0.16 & \pm 0.02 & $\mathrm{a}$ & 34 \\
\hline & 2007 & - & 80.1 & \pm 1.7 & $\mathrm{a}$ & 2.7 & \pm 0.9 & $\mathrm{~b}$ & 0.20 & \pm 0.02 & $\mathrm{a}$ & 51 \\
\hline \multirow{3}{*}{ Georgia Green } & 2006 & 92 & 81.2 & \pm 1.7 & $b^{d}$ & 4.2 & \pm 1.1 & $a^{d}$ & 0.15 & \pm 0.02 & $b^{d}$ & 47 \\
\hline & 2007 & 91 & 82.2 & \pm 2.0 & $\mathrm{~b}$ & 3.9 & \pm 1.2 & $\mathrm{a}$ & 0.17 & \pm 0.02 & $\mathrm{~b}$ & 38 \\
\hline & 2008 & 86 & 86.9 & \pm 1.3 & $\mathrm{a}$ & 0.8 & \pm 0.8 & $\mathrm{~b}$ & 0.22 & \pm 0.02 & $\mathrm{a}$ & 33 \\
\hline \multirow{2}{*}{ Georgia-01R } & 2006 & 68 & 63.0 & \pm 3.1 & $\mathrm{a}$ & 8.5 & \pm 2.8 & $\mathrm{a}$ & 0.11 & \pm 0.02 & $\mathrm{~b}$ & NA \\
\hline & 2007 & 87 & 37.8 & \pm 1.8 & $\mathrm{~b}$ & 1.0 & \pm 0.8 & $\mathrm{~b}$ & 0.20 & \pm 0.05 & $\mathrm{a}$ & NA \\
\hline \multirow{3}{*}{ Georgia-02C } & 2006 & 93 & 81.1 & \pm 3.3 & a & 12.4 & \pm 2.6 & $\mathrm{a}$ & 0.09 & \pm 0.01 & $\mathrm{~b}$ & 67 \\
\hline & 2007 & 98 & 64.0 & \pm 1.8 & c & 3.1 & \pm 1.1 & $\mathrm{~b}$ & 0.16 & \pm 0.02 & $\mathrm{a}$ & NA \\
\hline & 2008 & 90 & 68.5 & \pm 1.4 & $\mathrm{~b}$ & 0.9 & \pm 0.4 & c & 0.16 & \pm 0.02 & a & NA \\
\hline \multirow{2}{*}{ Georgia-03L } & 2006 & 93 & 69.7 & \pm 2.8 & $\mathrm{a}$ & 9.4 & \pm 3.3 & $\mathrm{a}$ & 0.15 & \pm 0.03 & $\mathrm{a}$ & NA \\
\hline & 2007 & 88 & 52.2 & \pm 1.8 & $\mathrm{~b}$ & 2.5 & \pm 1.3 & $\mathrm{~b}$ & 0.20 & \pm 0.04 & $\mathrm{a}$ & NA \\
\hline \multirow{2}{*}{ Georgia-06G } & 2007 & 98 & 94.3 & \pm 1.6 & $\mathrm{a}$ & 3.6 & \pm 1.0 & a & 0.21 & \pm 0.02 & $\mathrm{a}$ & 30 \\
\hline & 2008 & 90 & 91.6 & \pm 1.5 & $\mathrm{a}$ & 1.8 & \pm 0.5 & $\mathrm{~b}$ & 0.16 & \pm 0.01 & $\mathrm{~b}$ & 45 \\
\hline \multirow{2}{*}{ York } & 2007 & 95 & 62.0 & \pm 2.1 & $\mathrm{~b}$ & 2.2 & \pm 0.9 & $\mathrm{a}$ & 0.15 & \pm 0.02 & $\mathrm{a}$ & NA \\
\hline & 2008 & 90 & 88.2 & \pm 1.6 & $\mathrm{a}$ & 2.5 & \pm 0.7 & a & 0.14 & \pm 0.01 & $\mathrm{a}$ & 42 \\
\hline
\end{tabular}

a Official Georgia Crop Improvement Association testing regulations, 75\% for certified seed by AOSA. Year seed were grown, and tested the following year prior to seed planting.

${ }^{b}$ Abbreviations: CL, confidence limit; Germ 80 , cumulative growing-degree day value at $80 \%$ germination; NA, not applicable as the seed lot of that cultivar did not achieve $80 \%$ germination over the duration of the assay; GDD, growing-degree day.

'Parameter estimates calculated by nonlinear regression equation, $Y=a / 1+\left[((a-b 1) / b 1) * \mathrm{e}^{(-b 2 x)}\right]$ for seed germination with respect to time based on GDD accumulation: $a$ is the height of the horizontal asymptote at a very large $X, b 1$ is expected value of $Y$ (cumulative germination) at time $X=0$, and $b 2$ is a measure of growth rate.

${ }^{\mathrm{d}}$ Values for each parameter within a column for each cultivar followed by the same letter are not significantly different at the 5\% probability level. General linear models procedures were used with mean separation using $95 \%$ asymptotic confidence intervals. To obtain the equation for the respective regression line in Figure 1, the parameters from this table are used.

$10 \mathrm{~cm}$ along the length of the table for a total of 24 dishes per seed lot. Beginning 24 hours after seeding, peanut seed germination was counted when the radicle extended more than five $\mathrm{mm}$ beyond the seed, and then the seed was removed from the dish. Tests were run seven days with counts taken daily. All counts were taken in less than one hour each day at approximately the same time, depending upon when an experiment was started the previous day. All counts were made beginning each day on the cold end working toward the high end with multiple people participating. The entire experiment was replicated three times each year for each seed lot cultivar with 24 Petridishes in each replication (240 seed per replication, 720 seed per cultivar seed lot). Germination data was converted to a percentage by day, and cumulative germination was determined for each Petri dish over the duration of that assay.

2.4. Thermal Gradient Data. Since there were 216 cells and only 100 thermocouples, data for the 100 thermocouples was used to predict individual cell temperature. Temperature data recorded by the data logger for each experiment (100 thermocouples) was used to establish temperature maximum and minimum $\left( \pm 0.5^{\circ} \mathrm{C}\right.$ for each thermocouple $)$ by cell 

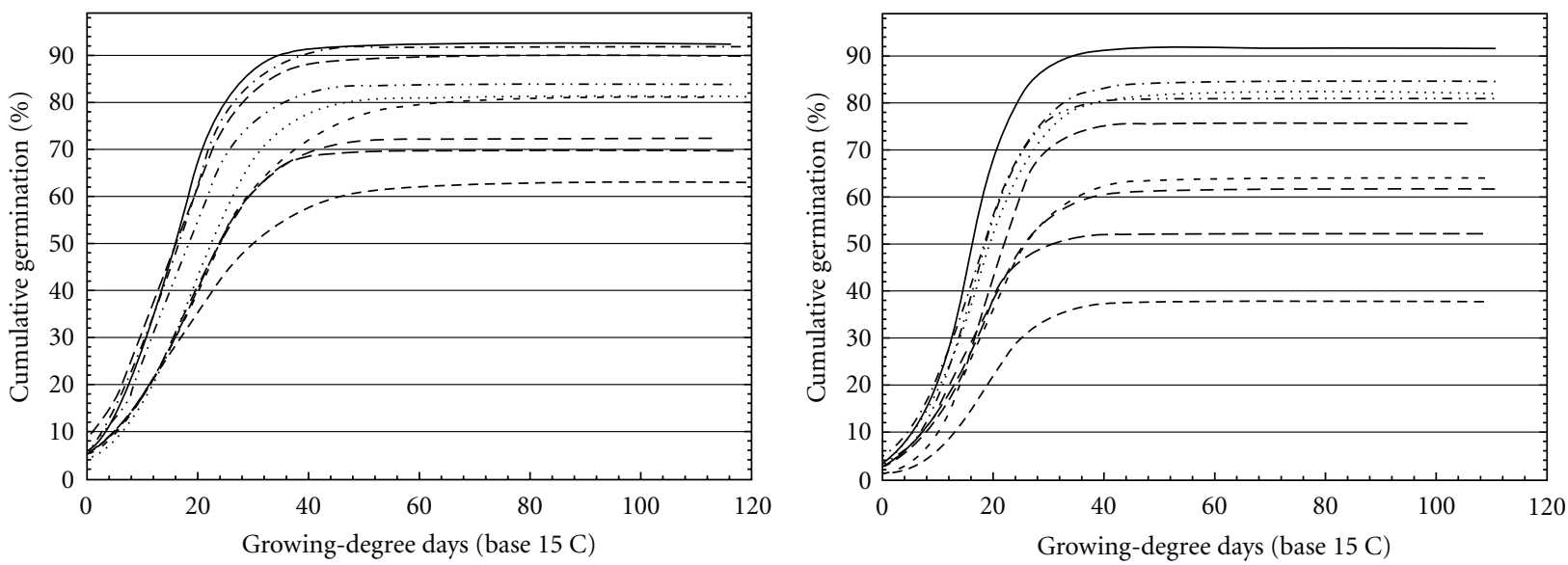

$\begin{array}{ll}- \text { AP3 } & \ldots . . \text { Georgia Green } \\ -\ldots \text { AT 3085RO } & --- \text { Georgia-01R } \\ -- \text { AT 3081R } & --- \text { Georgia-O2C } \\ \ldots \text { C-99R } & -- \text { Georgia-O3L } \\ \ldots \text { Carver } & \end{array}$

(a) 2006 cultivar seed lots

$$
\begin{aligned}
& \text {.... Georgia Green } \\
& \text { - - - Georgia-01R } \\
& \text { - - - Georgia-02C } \\
& \text { - - Georgia-03L }
\end{aligned}
$$

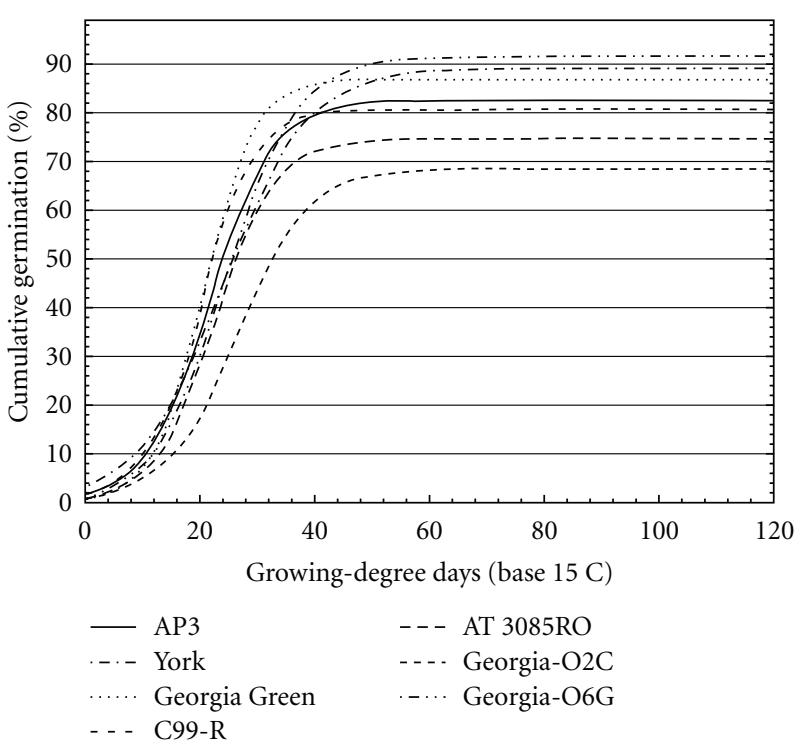

(c) 2008 cultivar seed lots

Figure 1: Cumulative germination patterns for Georgia runner-type peanut seed lots produced in 2006 (a), 2007 (b), and 2008 (c), based on nonlinear regression using growing-degree day (GDD) accumulation with a base temperature $15^{\circ} \mathrm{C}$. To calculate the regression equation for the respective seed lot, the parameter estimates shown in Table 1 for the equation $Y=a / 1+\left[((a-b 1) / b 1) * \mathrm{e}^{(-b 2 x)}\right]$ were used. Germination was measured on a thermal gradient.

coordinate number with prediction data generated by the three-dimensional equation

$$
z=z 0+a x+b y
$$

where $z$ is the predicted temperature, $x$ is the row number coordinate, $y$ is the column number coordinate, and $z 0, a$, and $b$ are predicted parameters. Maximum and minimum temperatures were the highest and lowest measures, respectively, taken during one germination experiment for a specific set of seed lot cultivars. These data from (1) were then used to predict the maximum and minimum temperature for each cell coordinate. These data were then used to determine the thermal time $[30,31]$ or growing degree day (GDD) accumulation for the equation

$$
t_{n}=\sum_{i=1}^{n}\left[\frac{T i_{\max }+T i_{\min }}{2}-T_{b}\right] \text {, }
$$

where $t_{n}$ is the sum of GDD for $n$ days, and $T i_{\max }$ and $T i_{\min }$ are the daily maximum and minimum temperature $\mathrm{C}$ of Day $i$ [30], and $T_{b}$ is the base temperature for peanut in this model $T_{b}$ was set at $15^{\circ} \mathrm{C}$ [32]. 
2.5. Data Analysis. For all measurements, analysis of variance (ANOVA) was applied to the data combined across cultivar (seed lot), experiment replication in time, and year to test for interactions. Years were regarded as random factors, while cultivars (seed lot cultivar within a year) and seed germination thermal times were considered fixed effects. Interactions between cultivar (seed lots) and these factors were used as error terms.

Nonlinear regression using the logistics growth curve with three parameters was used to model data [33]. The equation

$$
Y=\frac{a}{1+\left[((a-b 1) / b 1) * \mathrm{e}^{(-b 2 x)}\right]}
$$

with the parameters $a$ being the height of the horizontal asymptote at a very large $X, b 1$ the expected value of $Y$ at time $X=0, b 2$ is the measure of growth rate, and $Y$ is the predicted seed germination. One indicator of seed vigor is the number of GDD required to reach the $80 \%$ germination rate $\left(\mathrm{Germ}_{80}\right) . \mathrm{Germ}_{80}$ was then determined by solving the logistic growth curve equation using the parameter estimates for each seed lot cultivar setting $Y=80 \%$.

Data for cultivar (seed lot) equations were subjected to ANOVA using the general linear models procedures with mean separation using 95\% asymptotic confidence intervals. The 95\% confidence limits of three parameters in the equations were used to compare the significant differences for equation [3]. Nonlinear regressions were used to fit data using SAS NLIN (SAS Institute Inc. 2008. SAS OnlineDoc(r) 9.2 Cary, NC: SAS Institute Inc.) and graphed using SigmaPlot 11.0 (SigmaPlot 11.0. SPSS Inc. 233 S. Wacker Dr., 11th Floor, Chicago, Ill, USA).

\section{Results and Discussion}

3.1. Test Results. Significant cultivar-by-year interactions prevented the data from being combined by seed lot cultivar across tests. Therefore, data for the 2007, 2008, and 2009 seed experiments were analyzed separately and presented by seed lots of each cultivar (Table 1).

3.2. Germination and Temperature. There are three primary requirements for seed germination: heat, water, and oxygen. Temperature was the only variable in this study and an important factor influencing peanut seed germination in the field $[15,32]$. Germination patterns against temperature under thermal times were consistent from year to year (Data not shown). Patterns were nonlinear in progression; germination began slowly at low temperatures followed by a rapid growth phase from 20 to $32^{\circ} \mathrm{C}$ and then remained constant or declined slightly. The optimum temperatures for experiments were 29 and $30^{\circ} \mathrm{C}$ for all intervals greater than $24 \mathrm{hrs}$. ANOVA for germination rate indicated, there were no differences between the thermal ranges from 22 to $36^{\circ} \mathrm{C}$ for $72 \mathrm{hrs}, 96 \mathrm{hrs}$, and $120 \mathrm{hrs}$ (Data not shown). These data indicate that 72 hrs was the optimum thermal time for a rapid germination test using the thermogradient process. Correlation coefficients for the 2006 and 2007 seed lots between
$120 \mathrm{hrs}$ and $24,48,72$, and $96 \mathrm{hrs}$ were $0.11,0.72,0.84$, and 0.83 for 2006, and $0.80,0.93,0.98$, and 0.99 for 2007, respectively (data not shown). For these experiments, 72 hrs was highly correlated with $120 \mathrm{hrs}$ and was sufficient to predicate the maximum germination rate.

3.3. Germination Rate. ANOVA indicated significant differences in germination rate for years, cultivars, and interactions of the factors. ANOVA results by year indicated that cultivars and germination rate were significant for some peanut seed lots. The variation in germination rate among peanut seed lots of cultivars was apparent in 2006, 2007, and 2008 (Figure 1). Variation in peanut seed quality has been previously noted and can be associated with storage moisture content [34] as well as cultural and harvest practices [35].

Using 95\% confidence intervals, the three parameters in the polynomial sigmoidal curves were compared within cultivars over years [36]. Maximum germination rate (parameter $a$ ) for all but two cultivars (Carver and Georgia-06G) was different within a seed lot from year to year (Table 1). Seed lots of AP-3, AT-3081R, Carver, Georgia Green, and Georgia-06G maximum germination rates were all greater than $80 \%$ indicating that these seed were vigorous enough to overcome thermogradient stresses of heat and cold. Seed lots of AT 3085RO, C-99R, Georgia-01R, Georgia-02C, Georgia$03 \mathrm{~L}$, and York had variable maximum germination rates ranging from 38 to $92 \%$, indicating that various seed lots had low vigor which was expressed by the thermogradient stresses of heat and cold. Overlap existed in parameters $b 1$ and $b 2$ in most of cultivars, indicating that the initial germination rate and growth speed were similar (Table 1).

3.4. Peanut Seed Vigor. Two indices can be obtained from the equation to elucidate the seed germination performance of seed lots of each cultivar. One is maximum germination rate as presented as parameter $a$ in the equation. The other is the GDD value at Germ 80 , as previously described as an indication of seed vigor. The lower the Germ 80 value, the stronger the seed vigor. Based on the two indices, seed lots of Carver, Georgia Green, Georgia06G, AP-3, and AT 3081R had the strongest and most consistent seed vigor with Germ 80 of less than 51, 47, 45, 40, and 32 GDD, respectively (Table 1). Other seed lots of cultivars, including C99-R, Georgia01R, Georgia-02C, and Georgia-03L, had inconsistent seed performance, failing to achieve $80 \%$ germination in at least two of the years.

While Georgia Green was the most consistent cultivar from 2006 to 2008 seed lots, Georgia-06G maximum germination rate exceeded $91 \%$ for seed lots from 2007 and 2008. Growers have utilized Georgia Green for over 10 years across the southeast peanut production region due to its seed reliability and other agronomic traits. Georgia-06G is readily being adopted by growers and with high maximum germination rates, and this will likely add to its successful adoption. Variation in standard peanut seed germination testing by various laboratories has been noted [37]. Sullivan and Wynne [37] reported that standard germination testing was a satisfactory estimate for relative seed quality for 
a specific seed lot but noted that field emergence did not always correlate with germination testing.

\section{Summary}

These data indicated that a thermal gradient apparatus successfully evaluated peanut seed lot cultivars for seed vigor, and that analysis using the logistics growth curve provided information on seed germination characteristics. Comparing data generated from the thermal gradient using the logistics growth curve model gave different maximum germination rates as compared to standard germination testing results (Table 1). C-99R standard germination for 2006 and 2007 was 83 and $91 \%$, while the maximum growth rates using the thermal gradient were 72 and $62 \%$, respectively. Georgia 01R standard germination was $87 \%$ in 2007 , but the maximum growth rate was $38 \%$. Standard seed germination testing of lots of Georgia 02C for 2007 and 2008, Georgia 03L in 2006 and 2007, and York in 2007 had similar standard germination testing of $88 \%$ and greater, but all had maximum growth rates of $70 \%$ and less. While cold germination testing can be used as a measure to stress peanut to evaluate vigor [17], the thermal gradient apparatus used to evaluate peanut cultivars in this study established variation in seed vigor across a wide range of temperatures simultaneously.

The thermal gradient method of seed evaluation provided an indication of vigor, which may assist growers in determining the success of the cultivar over a range of temperatures, unlike the standard peanut germination test [18]. These results also indicated that differences in germination were detectable within $72 \mathrm{hrs}$ at temperatures ranging from 15 to $30^{\circ} \mathrm{C}$. These data assisted in determining variation between seed lots among various peanut cultivars when grown by seed producers under unknown environmental conditions. Future research should emphasise comparisons using this technique for peanut seed grown under known environments to determine if variations in seed vigor exist among cultivars.

\section{Acknowledgments}

The authors would like to thank the Georgia Peanut Commission for partial funding of this project and support from the University of Georgia and USDA/ARS. The authors also thank Charlie Hilton, Aaron Wise, and Rebecca Wallace for technical assistance.

\section{References}

[1] United States Department of Agriculture-National Agricultural Statistics Service (USDA-NASS), "Crop Production Annual Summary,” 2010, http://www.nass.usda.gov.

[2] P. V. Prasad, K. J. Boote, J. M. Thomas, L. H. Allen Jr., and D. W. Gorbet, "Influence of soil temperature on seedling emergence and early growth of peanut cultivars in field conditions," Journal of Agronomy and Crop Science, vol. 192, no. 3, pp. 168-177, 2006.

[3] A. K. Culbreath, J. W. Todd, and J. W. Demski, "Productivity of Florunner peanut infected with tomato spotted wilt virus," Peanut Science, vol. 19, pp. 11-14, 1992.
[4] A. K. Culbreath, J. W. Todd, D. W. Gorbet et al., "Reaction of peanut cultivars to spotted wilt," Peanut Science, vol. 27, pp. 35-39, 2000.

[5] B. L. Tillman, D. W. Gorbet, and P. C. Andersen, "Influence of planting date on yield and spotted wilt of runner market type peanut," Peanut Science, vol. 34, pp. 79-84, 2007.

[6] W. D. Branch, J. A. Baldwin, and A. K. Culbreath, "Genotype by seeding rate interaction among TSWV-resistant, runnertype peanut cultivars," Peanut Science, vol. 30, pp. 108-111, 2003.

[7] W. D. Branch, "Registration of "Georgia Green" peanut," Crop Science, vol. 36, p. 806, 1996.

[8] W. D. Branch and S. M. Fletcher, "Evaluation of advanced Georgia peanut breeding lines with reduced-input and without irrigation," Crop Protection, vol. 23, no. 11, pp. 1085-1088, 2004.

[9] C. C. Holbrook, P. Timper, W. Dong, C. K. Kvien, and A. K. Culbreath, "Development of near-isogenic peanut lines with and without resistance to the peanut root-knot nematode," Crop Science, vol. 48, no. 1, pp. 194-198, 2008.

[10] C. C. Holbrook, P. Timper, and A. K. Culbreath, "Resistance to tomato spotted wilt virus and root-knot nematode in peanut interspecific breeding lines," Crop Science, vol. 43, no. 3, pp. 1109-1113, 2003.

[11] A. K. Culbreath, J. W. Todd, T. G. Isleib et al., "High levels of field resistance to tomato spotted wilt virus in peanut breeding lines derived from hypogaea and hirsuta botanical varieties," Peanut Science, vol. 32, pp. 20-24, 2005.

[12] B. R. Morton, B. L. Tillman, D. W. Gorbet, and K. J. Boote, "Impact of seed storage environment on field emergence of peanut cultivars," Peanut Science, vol. 35, pp. 108-155, 2008.

[13] J. P. Moss and V. R. Rao, "The peanut-reproductive development to plant maturity," in Advances in Peanut Science, H. E. Pattee and H. T. Stalker, Eds., American Peanut Research and Education Society, Stillwater, Okla, USA, 1995.

[14] T. H. Sanders, A. M. Schubert, and H. E. Pattee, "Maturity methodology and postharvest physiology," in Peanut Science and Technology, H. E. Pattee and C. T. Young, Eds., American Peanut Research and Education Society, Stillwater, Okla, USA, 1982.

[15] M. A. Awal and T. Ikeda, "Effects of changes in soil temperature on seedling emergence and phenological development in field-grown stands of peanut," Environmental and Experimental Botany, vol. 47, no. 2, pp. 101-113, 2002.

[16] J. F. Spears, D. L. Jordan, and J. E. Bailey, Peanut Seed Prodution: A Guide for Producers of Virginia-Type Peanut Production, North Carolina Cooperative Extension Service, 2002.

[17] W. R. Guerke, "Evaluating peanut seed vigor," Seed Technology, vol. 27, pp. 121-126, 2005.

[18] Association of Official Seed Analysts, Rules for Seed Testing, Association of Official Seed Analysts, Las Cruces, NM, USA, 2002.

[19] J. Cardina and J. E. Hook, "Factors influencing germination and emergence of Florida beggarweed (Desmodium totruosum)," Weed Technology, vol. 3, pp. 402-407, 1989.

[20] N. Chatterton and A. Kadish, "A temperature gradient germinator," Agronomy Journal, vol. 61, pp. 643-644, 1969.

[21] S. C. Mohapatra and W. H. Johnson, "A thermogradient incubator for seed germination studies," Agronomy Journal, vol. 78, pp. 351-356, 1986.

[22] D. W. Gorbet, "Registration of “AP-3" peanut," Journal of Plant Registrations, vol. 2, pp. 126-127, 2007. 
[23] W. D. Branch, "Registration of "Georgia-02C" peanut," Crop Science, vol. 43, pp. 1883-1884, 2003.

[24] D. W. Gorbet and F. M. Shokes, "Registration of "C-99R" peanut," Crop Science, vol. 41, p. 2207, 2002.

[25] W. D. Branch, "Registration of "Georgia-03L" peanut," Crop Science, vol. 44, pp. 1485-1486, 2004.

[26] D. W. Gorbet, "Registration of "Carver" peanut," Crop Science, vol. 46, pp. 2713-2714, 2006.

[27] W. F. Anderson and J. E. Harvey, "Registration of "AT 3081R" peanut," Crop Science, vol. 46, pp. 467-468, 2006.

[28] W. D. Branch, "Registration of "Georgia-01R" peanut," Crop Science, vol. 42, pp. 1750-1751, 2002.

[29] W. D. Branch, "Registration of "Georgia-06G" peanut," Journal of Plant Registrations, vol. 2, pp. 88-91, 2008.

[30] D. L. Ketring and T. G. Wheless, "Thermal time requirements for phonological development of peanut," Agronomy Journal, vol. 81, pp. 910-917, 1989.

[31] G. S. McMaster and W. W. Wilhelm, "Growing degree-days: one equation, two interpretations," Agricultural and Forest Meteorology, vol. 87, no. 4, pp. 291-300, 1997.

[32] D. L. Ketring, R. H. Brown, G. A. Sullivan, and B. B. Johnson, "Peanut physiology," in Peanut Science and Technology, H. E. Pattee and C. T. Young, Eds., American Peanut Research and Education Society, Stillwater, Okla, USA, 1982.

[33] R. J. Freund and R. C. Littell, SAS System for Regression, SAS Institute, Cary, NC, USA, 1991.

[34] S. Navarro, E. Donahaye, R. Kleinerman, and H. Haham, "The influence of temperature and moisture content on the germination of peanut seeds," Peanut Science, vol. 16, pp. 6-9, 1989.

[35] D. E. McLean and G. A. Sullivan, "Influence of cultural and harvest practices on peanut seed quality," Peanut Science, vol. 8, pp. 145-148, 1981.

[36] C. Y. Chen and R. L. Nelson, "Variation in early plant height in wild soybean," Crop Science, vol. 46, no. 2, pp. 865-869, 2006.

[37] G. A. Sullivan and J. C. Wynne, "Variability in test of peanut seed germination," Journal of Seed Technology, vol. 4, pp. 1217, 1979. 


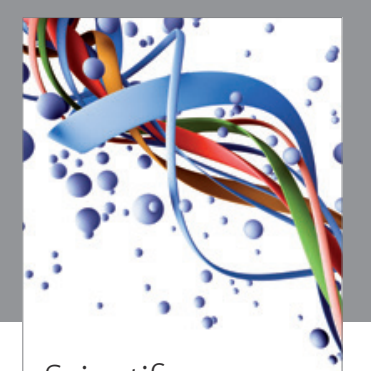

Scientifica
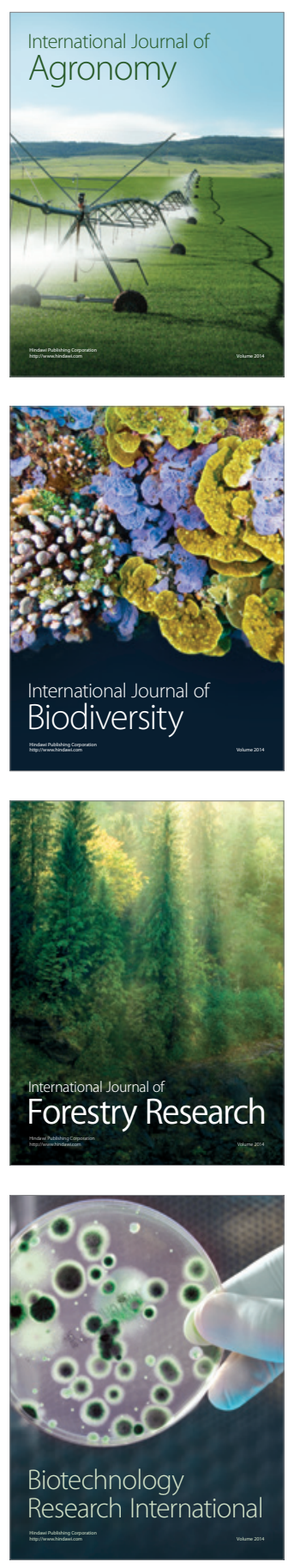
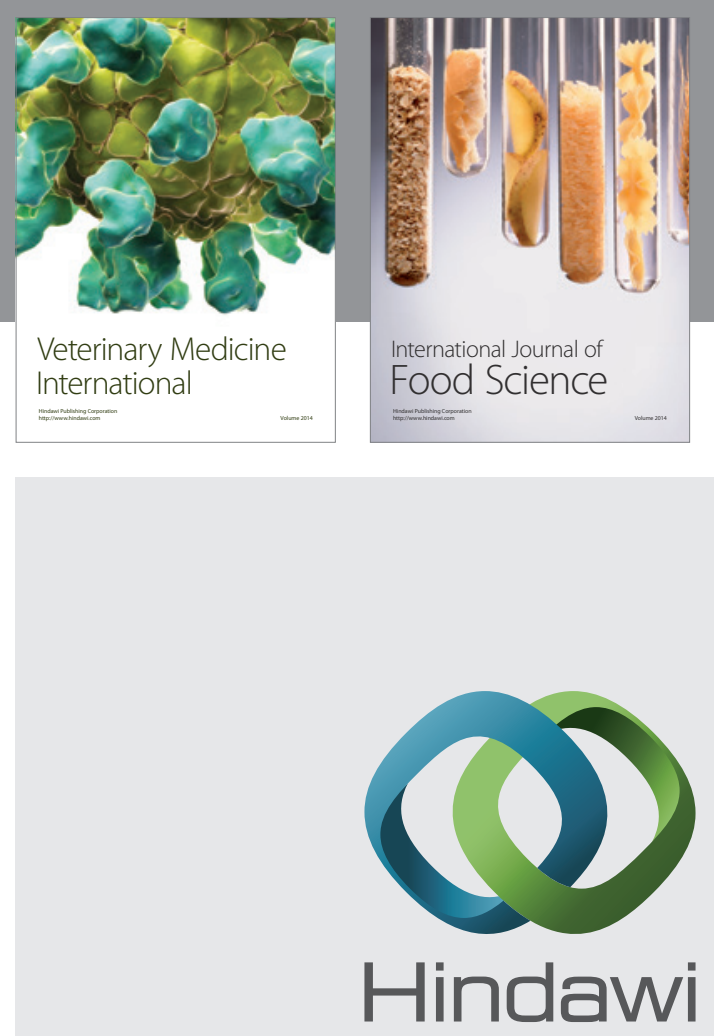

Submit your manuscripts at

http://www.hindawi.com
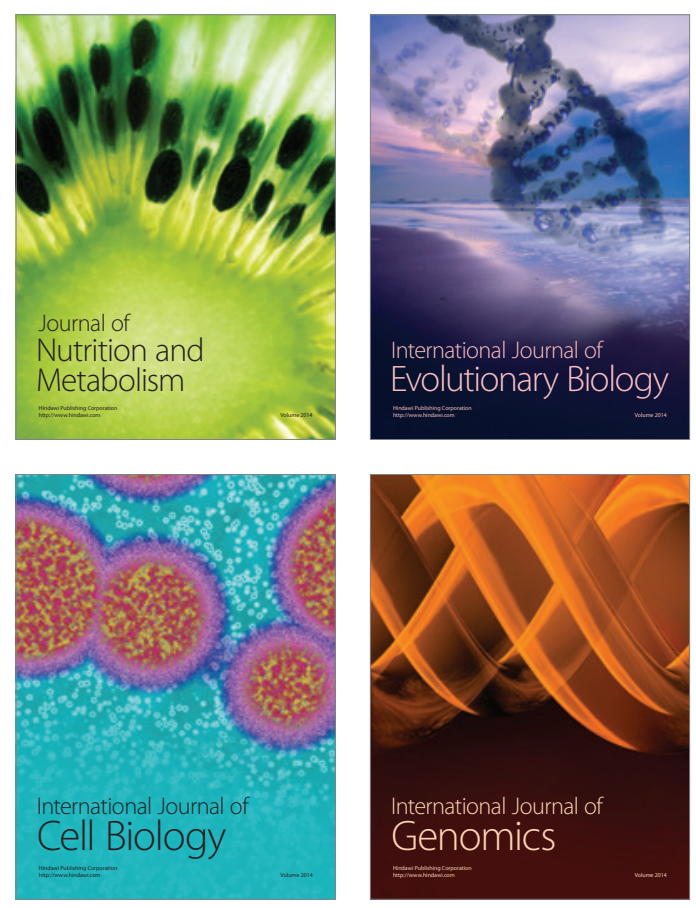
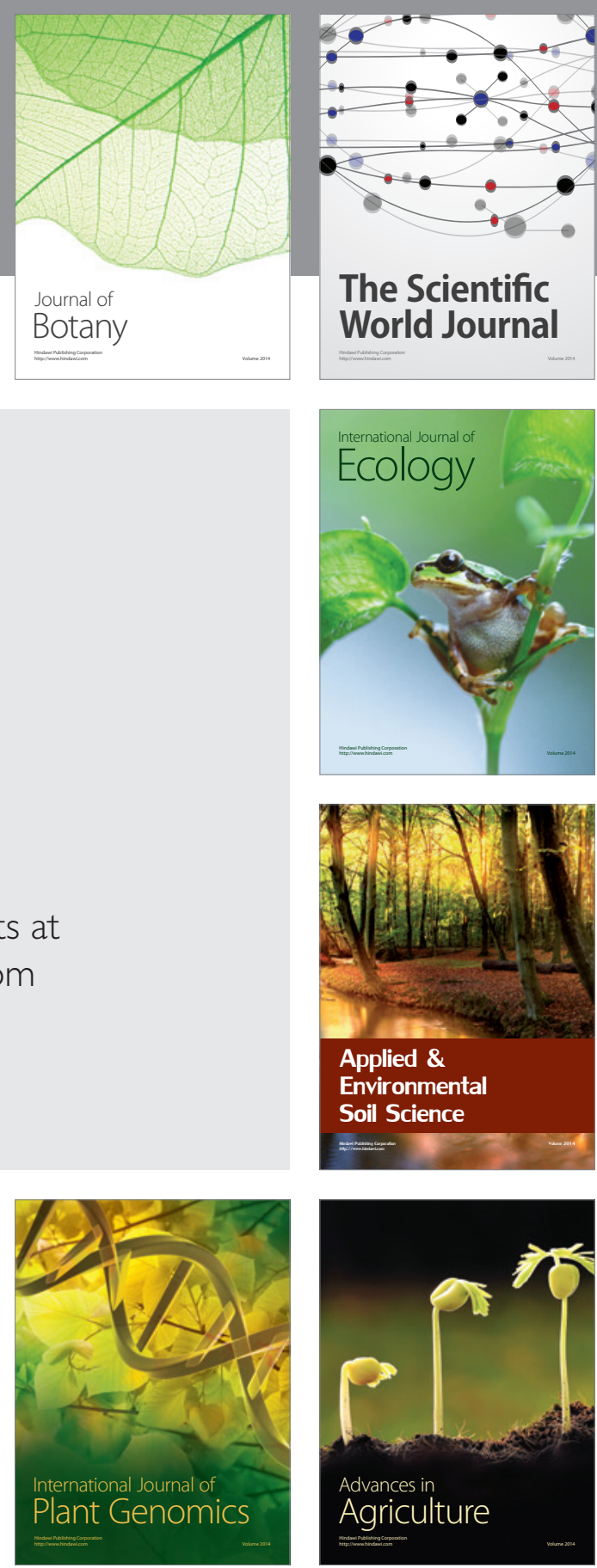

The Scientific World Journal
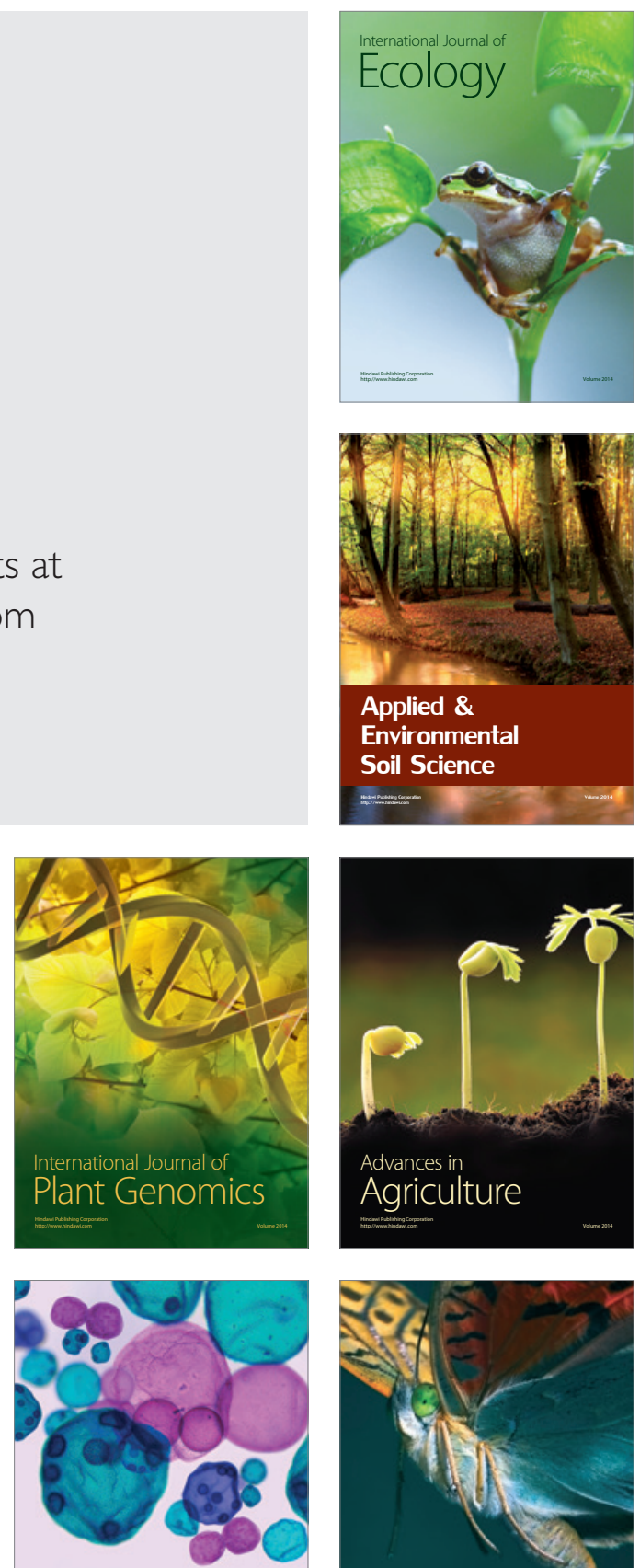

International Journal of Microbiology

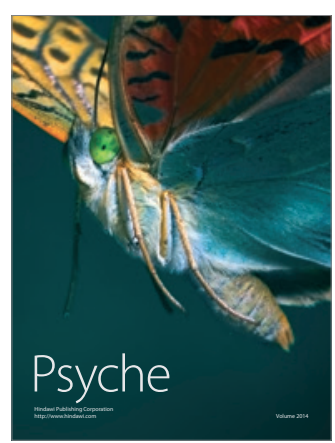

